\title{
Development of Mathematics Learning Instrument Based on Problem Based Learning to Improve Students' Mathematical Critical Thinking Skill of Student in Class X Vocational High School
}

\author{
$1^{\text {stPil Gafur }}$ \\ Mathematics and Science Faculty \\ Universitas Negeri Padang \\ Padang, Indonesia
}

\author{
$2^{\text {nd }}$ I Made Arnawa \\ Mathematics and Science Faculty \\ Universitas Andalas \\ Padang, Indonesia \\ Arnawa1963@gmail.com
}

\begin{abstract}
The analysis result of preliminary research conducted at Vocational High School 6 Padang revealed that students' mathematical critical thinking skill has yet to be made optimum. One of the reason is the unavailability of learning device to facilitate students to improve their mathematical critical thinking skill. This is the motivation to develop mathematics learning instrument in the forms of Lesson Plan (RPP) and Student Worksheet (LKPD) with Problem Based Learning which involves students directly to find the concept of learning material by themselves to allow comprehension of the knowledge for both oral and written. Data were collected through observation, documentation, questionnaire and interview. The research subject is students of class X Culinary in Public Vocational High School 6 Padang. This is a development research employing Plomp model which consists of needs analysis, student needs analysis, curriculum analysis, and concept analysis. The prototype stage is to design products such as RPP and LKPD with Problem Based Learning, and then to conduct the formative evaluation to determine product validity and practicality. The assessment phase is to conduct a practicality test and effectiveness test. The purpose of this research is to produce mathematical learning instrument with problem based learning for class $X$ Vocational High School which is valid, practical and effective.
\end{abstract}

Key Words - Mathematical Critical thinking skill, Learning Skill, Learning Instrument, Problem Based Learning, PlompModel.

\section{INTRODUCTION}

Globalization and the progress of information technology require qualified human resources. In order to produce qualified human resources. One of the educational institution to produce qualified and competent human resources in the work field is Vocational High School. A qualified human resources are comprehensive in thinking and always prepare for the future requirement, show a positive attitude, well behaved, and insightful, and have the ability, skill, and expertise which is relevant with any working field.

Learning subject in the Vocational High School consists of adaptive, normative and productive ones. Yulianti (2010) stated that adaptive learning subject supports the productive learning subject (vocational) since the adaptive learning subject allows students to comprehend and to master the concept and basic principle of science and technology. These can be implemented in the daily life as to be the basic of work competence [1]. Mathematics in the vocational high school is one of the adaptive learning subjects. It is expected that Mathematics learning is not merely about teaching the students about mathematics concept but to allow the students to utilize the concepts to solve the problems exist in their productive learning subject.

The purposes of mathematics learning in the vocational high school according to the regulations of ministry of national education No.22 Year 2006 are: (1) comprehend mathematics concept, describe the relationship among concepts and able to apply concept or algorithm in a well mannered, accurate, efficient and appropriate problem solving; (2) communicate idea with symbol, table, diagram or other media to clarified particular condition or problem; (3) show positive attitude toward the use of mathematics in real life situation namely curiosity, attentiveness and interest in learning mathematics, also persevering and self confident in problem solving [2].

Based on the above purposes, it can be concluded that among the purposes ought to be possessed by the students are problem solving skill and to develop their logical thinking. Ansjar and Sembiring in Yulianti (2010) revealed that this logical thinking is part of critical thinking skill which involves basic thinking, critical thinking, and creative thinking. Problem solving skill is the general purpose of mathematics learning. It means that mathematics may help to solve the problems for both in the other learning subjects and in daily life. To enable students to develop problem solving skill, students need to do each phase such as identify the problem, define the problem, provide a solution, and evaluate the problem. These phases are the process of critical thinking. Garrison (in Indahwati, 2015) stated that "an individual who thinks critically will meet five stages; identify the problems, define the problem clearly, explore the problem and possible solution, evaluate the implementation to finally integrate comprehension and existed knowledge" [3]. Based on Garrison statement, it can be concluded that those who think critically would possibly pass every stage of critical thinking skill in problem solving. Next, Johnson (in Karim 2011) stated that critical thinking is a life skill and certainly not a hobby in the academical field. In addition to that, Johnson revealed that critical thinking is a thinking 
hobby that can be developed by everyone. Hence, this hobby should be taught since Elementary School to High School levels [4].

According to Garrison and Johnson statements, it can be concluded that mathematical thinking skill is of vital importance to be developed for the students, particularly at the Vocational High School to enable the students to solve the problems they encounter structurally for both mathematics learning subject and other learning subjects. This is in line with the Department of National Education (2003) which revealed that critical thinking skill can be useful to face many possibilities and the characteristic of critical thinking skill can be best developed through mathematics learning [5].

The fact in the field shows that students critical thinking skill are still low which causes the students' learning result has optimum yet. This can be seen from the result of students daily test of class X Culinary in Public Vocational High School 6 Padang. There are only 8 to 12 students who pass the KKM (minimum completion standard). The percentage of result completion of students Daily Test of class X Culinary Public Vocational High School 6 Padang year 2017/2018 on the linear program can be seen in Table 1.1

TABle.1 The Completion Percentage of Student Daily Test $\begin{array}{llllll}\text { ClasS } X & \mathrm{X} \text { PULIC VOCATIONAL High SCHOOL } 6\end{array}$ PADANGACADEMIC YEAR 2017/2018 ON LINEAR PROGRAM MATERIAL.

\begin{tabular}{|c|c|c|c|}
\hline Class & $\begin{array}{c}\text { Number of } \\
\text { students who } \\
\text { achieved } \\
\text { completion }\end{array}$ & $\begin{array}{c}\text { Total } \\
\text { Students }\end{array}$ & $\begin{array}{c}\text { Completion } \\
\text { Percentage Per } \\
\text { class (\%) }\end{array}$ \\
\hline X KUL1 & 14 & 30 & 46,66 \\
\hline X KUL2 & 12 & 32 & 37,50 \\
\hline X KUL3 & 14 & 32 & 43,75 \\
\hline
\end{tabular}

Vocational High School 6Padang

According to Wahyudin (in Ningsih, 2012:4), the low mathematics learning achievement is caused by the effort in developing critical thinking skill at schools is rarely implemented so that the students critical thinking skill is very low [6]. Ruseffendi (2006), also stated that generally, conventional approach has a particular characteristic such as prioritize memorization over comprehension emphasize calculation skill, focus more on the result rather than process and teacher center, students involvement tend to be minimalized so that students mathematical thinking skill is not well developed [7].

The interview result conducted with mathematics teacher at Public Vocational High School 6 Padang and Public Vocational High School 1 Lembah Gumanti shows that $60 \%$ of students have not yet implemented active learning model. The students are still implementing the conventional learning model so that students critical thinking skill is low. In order to train a critical thinking skill, it is important to employ student center learning model, where teacher plays the role as a guide in the learning process (Tandogan, 2007) [8].

One of the ways to focus on students center is to use learning model which provides the students with more opportunities on the discussion, asking and answering the question, able to present their task both written and oral, and are able to develop mathematical critical thinking skill. Problem Based Learning (PBL) is expected to fulfill these expectations.

Problem Based Learning (PBL) is a learning model which focus on students problem solving process. It is a learning model which help the students to develop science in a flexible way. It can be implemented in many different institutions. It is also one of the learning that may help to stimulate critical thinking skill. This is in line with Herman (2007) who revealed that Problem Based Learning (PBL) can help the students to develop their critical thinking skill, to adapt to the new knowledge, and to stimulate students ability to discover a new knowledge [9].

According to Setyorini et. al (in Tarmizi, 2017), Problem Based Learning (PBL) Model can improve students critical thinking skill [10]. By employing this model, students can be trained to work together to find the solution toward problems they encounter. It is expected that by analyzing and solving the complex problem, students critical thinking skill can be improved (Akcay, 2009) [11]. Moreover, the research of Tosun and Taskesenligil (2012) concluded that instead of improving critical thinking skill or high order thinking skill, PBL learning model also may improve participation, activity, motivation, and students learning result [12].

Based on the observation and interview with the teacher at Public Vocational High School 6 Padang, it is known that learning instrument employed by the teacher consists of Lesson Plan (RPP), textbook and Student Worksheet (LKPD). However, these have not been fully useful in helping students on the learning process.

Based on the current analysis toward RPP, the activity that has already designed by a teacher is in line with 2013 curriculum. However, the activity mentioned in RPP has not yet helped the students to understand the concept from the material learned directly. At the core activity, a teacher asks students to observe the problem without necessarily mention the intended problem in RPP. Furthermore, teacher tends to directly explain the main idea of the learning material toward the students, provide the example of the question and goes directly to the exercise.

In the mathematical learning process, many teachers have not yet implemented the Students Worksheet. This is due to teacher consideration that most Vocational High School students dislike mathematics learning. The learning process is still using conventional learning and teacher still dominant in teaching and learning process so that the interaction between teacher-students and students and their peers cannot be made clear.

Based on the above problem, a teacher needs to develop a learning instrument based on students competence and interest in line with the program expertise of each teacher. Therefore, the researcher conducts a research entitled"The use of Problem Based Learning to Develop Mathematics Learning Instrument to Improve Mathematical Critical Thinking Skill of Student in ClassX Vocational High School". The developed learning instruments in this research are Mathematics Lesson Plan (RPP) and Students Worksheet (LKPD) with Problem Based Learning. It is expected that it may help the students to improve their critical thinking skill 
so that learning result can be achieved and in line with the learning purpose of the Vocational High School.

\section{METHODS}

This is a Research and Development/R\&D study. Sugiyono (2008: 297) stated that "Research and Development/R\&D" is a research method employed to study to produce a new product, in which later to test the effectiveness of the product" [13].

This research utilized Plomp model development. It consists of three stages, namely the preliminary research stage, the prototyping stage, and assessment stage (Plomp \& Nieveen,2013) [14]. Preliminary research stage consists of needs analysis, curriculum analysis, concept analysis, and students analysis. Needs analysis aimed to obtain information about problems in the mathematics learning process. Data were collected through classroom learning process observation and interview with the teacher.

Students analysis stage is conducted to reveal the students' characteristics such as what difficulties do the students experience during mathematics learning, to reveal students academic capacity, to get to know the learning material requires by the students. The data were obtained from interview with teacher and from the questonnaire distributed to students.

Curriculum analysis will analyze the implemented curriculum at school, particularly for mathematics learning subject of class X. Next, concept analysis is to provide detail of learning material as to design lesson plan through problem based learning.

The prototyping stage implement formative evaluation. This stage consists of prototype 1 is self evaluation; prototype 2 is expert review; prototype 3 is to do individual evaluation; prototype 4 is small group evaluation. The instrument validation conductced by three mathematics lecturers, one Indonesian language lecturer, and one Education Technology lecturer.

The assessment stage is to conduct field test at class $\mathrm{X}$ of Public Vocational High School 6 Padang to see the practicality and the effectiviness. Research data were obtained through self evaluation sheet, validation sheet, observation sheet and interview guidance, teacher response questionnaire sheet and student response questionnaire sheet, Lesson Plan implementation observation sheet, and critical thinking skill test.

\section{RESULT AND DISCUSSION}

This part contains result or research data, research data analysis, answer of the research question, and analysis toward finding during research.

Preliminary analysis were implemented to the students of class X Public Vocational High School 6 Padang and Public Vocational High School 1 Lembah Gumanti. Result of preliminary research consists of needs anlysis result, students analysis result, curriculum analysis, concept analysis.

\section{Needs Analysis Result}

This stage is to collect information about problems occur in the mathematics learning process at school. The information were collected through observation on teacher and students activity during teaching and learning process. The observation revealed that it is teacher center. Students experience difficulty in answering the question asked by teacher.

The interview with teacher showed that some teacher have implemented students worksheet (LKPD). However, it has not yet fully implemented in learning. This is due to the unavailability of learning steps to help student to be an independent learner. The interview result revealed that students ability is in great variety.

The solution toward the problem is to provide learning instrument particularly in the form of LKPD which may help to achieve learning purposes. According to The Department of National Education (2008), LKPD is sheets containing tasks that have to be done by the students"[15]. Normally, student worksheet in in the form of guidance, steps to finish certain task. LKPD must be based on the student center learning approach, also based on an activity whih can develop students' mathematics critical thinking skill. One of the ways to focus learning on the students activity in order to improve students mathematical critical thinking skill is Problem Based Learning (PBL).

Through student worksheet (LKPD) with PBL, students can develop their mathematical critical thinking skill (Setyorini et al in Tarmizi, 2017). Moreover, the developed student worksheet must be attractive for the students, so that students would be eager to use it. This is due to the interview result with some students which signified that students need an interesting learning material like attractive color, font, illustration and steps to answer the question.

\section{Students Analysis Result}

The next step is to obtain information about students characteristics. The first characteristic is students low academic achievement. This can be seen from students daily test result of class X Public Vocational High School 6 Padang. Only few of the students pass the minimum completion criteria (KKM). The percentage of students daily test completion of class X Public Vocational High School 6 Padang 2017/2018 on linear program learning material is presented on Table 1 .

TABle II. The Completion Percentage of Student Daily Test Class $X$ Public Vocational High SCHOOL 6 PADANGACADEMIC YEAR 2017/2018 ON LINEAR PROGRAM MATERIAL.

\begin{tabular}{|c|c|c|c|}
\hline Class & $\begin{array}{c}\text { Number of } \\
\text { students who } \\
\text { achieved } \\
\text { completion }\end{array}$ & $\begin{array}{c}\text { Total } \\
\text { Students }\end{array}$ & $\begin{array}{c}\text { Completion } \\
\text { Percentage Per } \\
\text { class (\%) }\end{array}$ \\
\hline X KUL1 & 14 & 30 & 46,66 \\
\hline X KUL2 & 12 & 32 & 37,50 \\
\hline X KUL3 & 14 & 32 & 43,75 \\
\hline
\end{tabular}

Source: Mathematics Teacher of ClassX Public Vocational High School 6Padang

Due to the lack of comprehension toward learning material, numbers of students are failing to reach the 
minimum completion criteria (KKM) which is 70 for mathematics learning subject. Most of the students agreed that mathematics is a difficult learning subject.

The second characteristic of students based on the interview and observation is that they find it convenient to ask question to their peers. It can be seen during teaching and learning process. It is obvious that the student tend to ask their peers about learning material that is difficult for them to comprehend. The students reveal that, asking their smarter peers could really help them to comprehend the learning material. The students are afraid of asking question directly to their teacher.

The third characteristic is that students less focus during learning process. When teacher presenting the learning material, most of the students are busy doing their private things such as talking to the friend sitting next to them, sleleping, eating and walking around the classroom. The fourth characteristic is many of them like to form a group up on an activity, such as hang out together in the school canteen and some other places. It indicates that students tend to do activity in a group.

Based on the students characteristics mentioned above, the researcher is interested in developing student worksheet (LKPD) based on PBL in order to fulfill the needs of students characteristics in the learning process. Student Worksheet (LKPD) with PBL based is a learning material which suits students characteristics who like to discuss and focus more on students during the learning process. Learning by using Student Worksheet (LKPD) with PBL based may help the students to engage actively since the beginning of the learning process.

\section{CurriculumAnalysis Result}

This stage is to analyze the 2013 curriculum of mathematics learning subject for class X Vocational High School. The purpose to analyze the curriculum is to assure that teaching material is in line with the target competence. Curriculum analysis focus on $\mathrm{KI}$ and $\mathrm{KD}$ analysis. It plays the role as a guidance in the development of mathematics learning instrument of PBL based for the students of class X Vocational High School. The analysis result of KI and KD in the content standard are transforming into competence achievement indicators. Based on the analysis result of mathematics learning subject syllabus of class X Vocational High School, it can be concluded that material that will be used to develop learning instrument is the first semester mathematics learning material of class X Vocational High School. For instance Powers of Numbers, logarithms, equations and inequalities of one variable absolute value, two-variable linear equation system, the linear program, sequence and series and growth and decay.

\section{Concept Analysis Result}

This is to determine the material needed in developing mathematics learning instrument with problem based learning. The main concept is that all of the learning material presented on learning instrument is based on PBL.

\section{CONCLUSION}

This is a Research and Development ( $R$ \& D) study aimed to produce a valid, practical and effective learning instrument based on PBL in the forms of Lesson Plan (RPP) and Student Worksheet (LKPD) in order to improve mathematical critical thinking of students at class $\mathrm{X}$ Vocational High School. The development process of learning instrument based on PBL for the students of class X Vocational High School is based on the Plomp development model which consist of three stages; preliminary research stage, development stage and assessment stage. Preliminary research stage consists of needs analysis, curriculum analysis, student analysis and concept analysis. The result of needs analysis is the characteristic of targeted learning instrument which is learning instrument based problem based learning in the form of Lesson Plan (RPP) and Student Worksheet (LKPD). The result of curriculum analysis is the transformation of basic competence into competence achievement indicator. The result of students analysis is the learning instrument characteristic which suits students characteristic. Meanwhile, the result of concept analysis is in the form of learning material sequence.

\section{REFERENCES}

[1] Yulianti, "Pengembangan Perangkat Pembelajaran Peluang Berbasis Reciprocal Teaching Untuk Melatih Kemampuan Berpikir Kritis Siswa Kelas XI SMK Negeri 3 Lubuklinggau”. Jurnal Pendidikan Matematika, Volume 4. No.1, Juli 2010.

[2] Depdiknas, Kurikulum Tingkat Satuan Pendidikan, Jakarta: Depdiknas, 2006.

[3] Indahwati. Rohmah, Model Pembelajaran Diskusi untuk Meningkatkan Kemampuan Berpikir Kritis Siswa, Jurnal Kependidikan Interaktif, Vol.10, No. 1, Januari 2015.

[4] Karim, Asrul. Penerapan Metode Penemuan Terbimbing Dalam Pembelajaran Matematika Untuk Meningkatkan Pemahaman Konsep Dan Kemampuan Berpikir Kritis Siswa Sekolah Dasar, Edisi Khusus No. 1. Agustus 2011. ISSN: $1412-565 X$

[5] Depdiknas, Kurikulum 2004 Standar Kompetensi Mata Pelajaran Matematika SMP/MTS. Jakarta: Depdiknas, 2003.

[6] Ningsih. E.F, Pengaruh Model Core Dengan Pendekatan Keterampilan Metakognitif pada Pembelajaran Matematika terhadap Kemampuan Berfikir Kritis Siswa SMA, UNPAS: Tidak Diterbitkan, (2012).

[7] Ruseffendi. E.T, Pengantar kepada Membantu Guru Mengembangkan Kompetensinya dalam Pengajaran Matematika untuk Meningkatkan CBSA, Bandung: Tarsito, 2006.

[8] Tandogan. R. O., Orhan. A, The Effects of Problem Based Active Learning in Science Education on Students' Academic Achievement, Attitude and Concept Learning, Online Submission, 3(1), 71-81, 2007.

[9] Herman. Tatang, Problem Based Learning untuk Meningkatkan Kemampuan Berpikir Matematis Tingkat Tinggi Siswa Sekolah Menengah Pertama, Educationist No. I Vol. I Januari. ISSN: 1907 8838, 2007.

[10] Tarmizi, "Penggunaan Lks Berbasis Pbl Terhadap Keterampilan Berpikir Kritis Siswa Pada Materi Cahaya Di Smpn 1 Kembang Tanjong", Jurnal Pendidikan Sains Indonesia, Vol. 05, No.01, pp 8793, 2017 Http://Jurnal.Unsyiah.Ac.Id/Jpsi, 2017.

[11] Akcay. Behiye, "Problem Based Learning in Science Education", Journal Of Turkish Science Education, 6 (1),27-36, 2009.

[12] Tosun. Cemal., Yavuz Taşkesenligil, "The Effect of Problem Based Learning on Student Motivation Towards Chemistry Classes and on Learning Strategies", Journal Of Turkish Science Education, 9 (1),127-131, 2012.

[13] Sugiyono, Metode Penelitian Kuantitatif Kualitatif dan R \& D, Bandung: Alfabeta, 2008.

[14] Plomp. T ., N. Nieveen, Educational Design Research, Enshede: Netherlands Institute For Curriculum Development (SLO), 2013.

[15] Depdiknas, Panduan Pengembangan Bahan Ajar, Jakarta: Direktorat Jenderal Manajemen Pendidikan Dasar dan Menengah,2008. 